This item was submitted to Loughborough's Research Repository by the author.

Items in Figshare are protected by copyright, with all rights reserved, unless otherwise indicated.

\title{
Global music city: knowledge and geographical proximity in London's recorded music industry
}

PLEASE CITE THE PUBLISHED VERSION

http://dx.doi.org/10.1111/j.1475-4762.2008.00793.x

\section{PUBLISHER}

(C) Royal Geographical Society (with The Institute of British Geographers). Published by Wiley

\section{VERSION}

AM (Accepted Manuscript)

\section{PUBLISHER STATEMENT}

This work is made available according to the conditions of the Creative Commons Attribution-NonCommercialNoDerivatives 4.0 International (CC BY-NC-ND 4.0) licence. Full details of this licence are available at: https://creativecommons.org/licenses/by-nc-nd/4.0/

\section{LICENCE}

CC BY-NC-ND 4.0

\section{REPOSITORY RECORD}

Watson, Allan. 2019. "Global Music City: Knowledge and Geographical Proximity in London's Recorded Music Industry”. figshare. https://hdl.handle.net/2134/21413. 
"Global Music City: Knowledge and Geographical Proximity in London's Recorded Music Industry"

\author{
Allan Watson \\ Postgraduate Researcher \\ Department of Geography \\ Loughborough University \\ Loughborough \\ Leicestershire LE11 3TU \\ England \\ A.Watson3@lboro.ac.uk
}




\title{
"Global Music City: Knowledge and Geographical Proximity in London's Recorded Music Industry"
}

\begin{abstract}
Drawing from debates in economic geography on relational and organisational proximity as a substitute for geographical proximity, the paper explores characteristics of knowledge transfer in London's recorded music industry through an examination of organisational connections on local and global scales. The paper demonstrates that knowledge transfer within the industry occurs simultaneously across multiple geographical scales, with certain organisational connections facilitating the transfer of tacit knowledge across organisational boundaries. However, the paper argues that these connections do not offer the same scope for trust as is afforded by frequent face-to-face contact and therefore offer only a partial substitute for geographical proximity.
\end{abstract}

\section{Key words}

London, Knowledge, Interviews, Clustering, Music Industry 


\section{Acknowledgments}

I am extremely grateful to Michael Hoyler and Phil Hubbard for their comments on this paper, as well as those of two anonymous referees. My thanks also go to Phil Soar for his assistance with the cluster mapping exercise. Earlier versions of this paper were presented at the Manchester: Music and Place

Conference at Manchester Metropolitan University, $8^{\text {th }}-10^{\text {th }}$ June 2006 , and the Futures of Music Conference 2006 at the University of Birmingham, $1^{\text {st }}-3^{\text {rd }}$ September 2006. 


\section{Introduction}

This paper is concerned with the spatial clustering of the music industry, as a global media industry. As Krätke (2003) suggests, few forms of globalisation can be observed or experienced so directly as the global circulation of symbols and images, and cultural commodities. A main characteristic of the globalisation of media industries is concentration in and around the key cities of global capitalism (see Morley and Robins, 1995, Robins, 1995, Scott, 2000b, 2001, 2002), concentrations that act as 'local anchoring points' in the 'cultural metropolises' of the global urban network (Krätke, 2003). UK cities are home to a significant number of creative clusters, and the contribution made to the economy by creative clusters of cultural and media industries in particular is increasingly being recognised (see DCMS, 2001a, 2001b). The paper focuses specifically on the clustering of recorded music industry firms in London. One of the most successful exporters of music to the world, London's music industry is important industry in terms of revenue and employment. Figures published by the Cultural Industries Task Force (DCMS, 2001a) for 1997/1998 estimated that of the total revenue of $£ 112.5$ billion of the creative industries, the UK music industry, led by London, generated £4.6bn (4\%), and employed 122,000 people, approximately $9 \%$ of the creative industries total of $1,322,000$. Industry exports totalled $£ 1.3$ million, approximately $13 \%$ of the total of $£ 10,252$ million for the creative industries.

Culturally-creative clusters within UK cities have been the subject of much recent academic work, such as the study of natural history film making in Bristol undertaken by Bassett et al (2002); studies of cultural production in cultural 
quarters in Manchester and Sheffield (Brown et al, 2000), and on the south bank of the River Thames, London (Newman and Smith, 2000). Many more studies have been undertaken on cultural clusters in cities outside the UK; see for example the work of Coe $(2000,2001)$ on the film industry in Vancouver; Scott on cultural economies in Los Angeles (1996) and Paris (2000a); and Christopherson and Storper (1986), Storper and Christopherson (1987), Aksoy and Robins (1992), and Scott (2002) on the clustering of the US motion picture industry in Hollywood. However, while such literature has explored issues surrounding the knowledge economy operating at the local scale, little empirical work has focused on knowledge networks operating across multiple spatial scales (see also Boggs and Rantisi, 2003, Gibson and Kong, 2005, and Scott et al, 2001).

\section{Clusters and Knowledge in the Global City}

In literature concerned with the knowledge economy, the geographical proximity of firms has been considered a necessary criterion for the stimulation of interactive learning (see Asheim, 2002, Storper and Venables, 2004). It is considered that relationships of trust are based on the shared experience of repeated interactions and transactions with decision-making agents in other firms (Gordon and McCann, 2003, Wolfe and Gertler, 2004). However, there is a developing concern that this focus may reinforce a set of powerful spatial discourses (Allen, 2000), which privilege one spatial scale for analysing knowledge (see Bunnell and Coe, 2001), resulting in clusters being viewed as impermeable producers and containers of knowledge. As Wolfe and Gertler (2004) suggest, a large component of the knowledge inputs to local production 
may be drawn from well outside the local cluster. The importance of the local scale may therefore have been overstated at the expense of understanding the role of global flows (Amin and Thrift, 1992, Boggs and Rantisi, 2003, Gibson and Kong, 2005, Scott et al, 2001). More recently the distanciated character of networks of knowledge has been recognised (Amin, 2000), and recent research on clusters has identified that local and global flows of knowledge may in fact be complementary. The relationship has been most commonly conceptualised by drawing on two concepts; those of local 'buzz' and global 'pipelines' (see Bathelt et al, 2004, Storper and Venables, 2004). Local buzz refers to the frequently used networks of information and communication developed through the face-to-face contact within a particular geographic cluster. This term has been associated with tacit forms of local knowledge, considered to be embedded in the cluster and difficult to transfer elsewhere (Maskell and Malmberg, 1999). Bathelt et al (2004) consider that this knowledge can be understood in a meaningful way because of the shared values, attitudes, interpretative schemes, and institutional and economic frameworks, possessed by those working in the same region (see Gertler, 2003, Pinch et al, 2003, and Wolfe and Gertler, 2004). Global pipelines represent a conceptualisation of the globally stretched networks of knowledge transfer that occur simultaneously with, and are complementary to, local learning networks. The central argument of Bathelt et al (2004) is that the co-existence of both high levels of local 'buzz' and well-developed global 'pipelines' are crucial to successful clusters, with the two providing different forms of learning. Therefore, it is not only the quality of the particular cluster within a given city that is important, but also, because they are themselves embedded within global networks, the links between local production and international circuits of capital, distribution, and knowledge 
(Amin and Thrift, 1992, Scott, 1997; see also Power and Hallencreutz, 2002, and Kloosterman, 2005, with particular reference to the music industry).

The problem with such a theorisation is that it creates a dichotomy between knowledge transfer and learning at local and global scales. Recent work has argued that these differentiated concepts might obscure important continuities in the nature of learning across global and local, and work such as that by Grabher (2001, 2002) and (Faulconbridge (2006a, 2006b) on the British advertising industry has highlighted that similar characteristics of learning at both urban and global scales may be facilitated by particular forms of social organisation. Amin and Cohendet (2000) suggest that both tacit and codified knowledge are now widely dispersed in 'communities of practice' (see also Gertler, 2001), and that competitive advantage is a result of how the two are combined (see also Amin and Thrift, 2000). The community of practice concept challenges the primary role of spatial proximity in knowledge transfer and learning, and highlights the importance of the context in which knowledge operates. Amin and Cohendet (1999) suggest that it is 'relational proximity', rather than geographical proximity, that constitutes the 'soft' architecture of learning. However, for Morgan (2004) this is problematic. Firstly, he argues that it juxtaposes relational and organisational proximity with geographical proximity; secondly, that there is an over exaggerated sense of what can be accomplished at distance; and finally that learning opportunities appear to be narrower than those on offer in 'ecologies of knowledge', such as those studied by Grabher $(2001,2002)$. For Morgan, while the spatial core of these ecologies may be in localised clusters, the boundaries may straddle multiple spatial scales because some of the firms that constitute the ecology are multi-locational organisations. 
The clustering of firms in global cities such as London must therefore be understood not only in terms of localised social interactions, but also with reference to the city's advantageous position within the 'intensified circuits' of the global space economy (Hubbard, 2006). A particular strand of global city research led by the work of Saskia Sassen $(1991,1994)$ has identified cities, in particular London, New York, and Tokyo as the key command and control points of the global economy. Taking a cue from such work, the Globalisation and World Cities (GaWC) research group, a network of global city researchers, has demonstrated that London is the most connected global city based on the specialised corporate services sector. This research has suggested that London sits on top of a group of ten cities GaWC have termed 'Alpha' world cities (see Beaverstock et al, 1999, 2000, 2003).

However, as Krätke and Taylor (2004) suggest, the globalisation of media industries is a neglected aspect of world city research. At the same time as the media multinationals located in cities interact locally with the small specialist producers and service providers, they run a global network of branch offices and subsidiaries that permits global linking of the urban centres of cultural production through established global networks (Krätke, 2003). Firms in media clusters are therefore not only embedded locally, but also integrated more widely through the international networks of the global media firms. Krätke (2003) has demonstrated that New York and London sit at the top of a group of 'Alpha world media cities', including Paris, Los Angeles, Munich, Berlin, and Amsterdam. Building on this, Krätke and Taylor (2004) have demonstrated that 
London is the highest ranked city by media connectivity, mirroring the city's ranking as a business service city.

\section{The Music Industry}

Three main types of companies lie at the centre of the industry, coordinating talent within networks of creativity and controlling networks of reproduction and distribution (Leyshon et al, 2005, see also Scott, 1999). Firstly, the major corporations of the industry, which are part of sophisticated global networks of marketing, promotion and distribution (Burnett, 1996). Four major multinational corporations currently dominate the global music industry. Universal has the largest of the music divisions, with a $25.5 \%$ share of the world market, followed by Sony BMG with a $21.5 \%$ share, EMI with a $13.4 \%$ share, and finally Warner with an $11.3 \%$ share (IFPI, 2005). Secondly, there are a large number of medium and large size independent companies, many of which tend to be involved in medium to long-term production and marketing arrangements with the major corporations (Burnett, 1996, Hesmondhalgh, 1996, Negus, 1992, 1999). Finally, an even greater number of small size independent recording companies operate as part of very localised independent networks of cultural production and distribution, often with little contact with the higher tiers of the industry.

The increased consolidation of the major corporations continues to change the global media landscape (Morley and Robins, 1995, Robins, 1995, see also Pratt, 2000). Perhaps the most significant development in this respect was the takeover of Time Warner by the Internet company AOL Online in 2000 (The Financial Times, January $11^{\text {th }} 2000$, The Economist, January $15^{\text {th }} 2000$ ), an 
event which was to fundamentally alter the competitive landscape for media companies and signal confidence in the possibilities of new technologies. Most recently, the merger of Sony Music Entertainment and BMG created a single music division and left only four industry majors. This trend looked likely to continue into the future, with EMI having a $\$ 4.5$ billion cash and shares bid for Warner Music rejected (The Times, May $24^{\text {th }} 2006$ ). However, following an appeal by independent companies fearing industry consolidation, a European court recently overturned the European Commission's merger approval of Sony and BMG (The Times Online, July $13^{\text {th }} 2006$, The Guardian Business, July $13^{\text {th }}$ 2006). This may result in their separation, and also throws into doubt the possible EMI takeover of Warner.

\section{Methodology and Mapping}

As Martin and Sunley (2003) suggest, the vague nature of the cluster concept does not lend easily to precise empirical delimitation. In this analysis, measurement begins with identification of co-location of record label and music publishing firms in London. This is achieved through a cluster mapping exercise, involving the compilation of a database of 1310 UK record label and music publishing firms from both music industry association membership lists and a comprehensive music industry listing publication (Collis, 2001). Identification of the clustering was achieved by measuring of the proximity of firms to each other. An iterative process was used to decrease the distance until distinct patterns of distributions emerged, at $400 \mathrm{~m}$. Figure 1, derived through the initial stage of the cluster mapping exercise, shows the distribution of music industry companies across the UK. The pattern of distribution has a strong relationship with the underlying geography of population. The number of 
companies within London is shown to be significantly larger (701 companies, $54 \%$ of the total) and more densely co-located than in other UK cities (see Figure 2). These findings are supported by the work of Nachum and Keeble (2003), Cook and Pandit (2005), and Pandit and Cook (2005), which highlights the strong geographical clustering of the media and broadcasting industries in London. The four major music divisions all have offices in London only, and the large number of companies in London indicates the presence of many local musical cultures offering specialised recording and business opportunities (Scott, 1999). The dispersion of companies across the UK also indicates local music cultures in larger provincial centres (see for example Brown et al, 2000). It is noted that the analysis is likely to have undercounted the number of small independent companies. Based on an arbitrary classification, four major clusters were identified, as shown in Figure 3. These are located around Notting Hill (96 companies), Soho (89 companies), Camden (38 companies), and Fulham (23 companies). Two minor clusters were identified around Acton (10 companies) and Shoreditch (10 companies). Based on the outcome of the mapping exercise, an extensive questionnaire survey was sent to 264 firms located in the four geographical clusters, to obtain contextual information. Unfortunately the limits of this paper prohibit specific discussion of the methodology and findings of this survey.

As Wolfe and Gertler (2004) outline, many analysts reject the idea that clusters can be adequately studied through quantitative methods alone, rather arguing that clusters can only be properly captured by using qualitative techniques. To move the analysis towards greater conceptual depth, semi-structured qualitative interviewing has also been employed in addition to quantitative top-down 
techniques, as part of a multi-method approach. Interviewing was considered a suitable method for two reasons. Firstly, there are likely to be practical limitations on being able to use more textured in-depth ethnographic research methods due to the size of the networks. Secondly, the music industry executives themselves are likely to impose limits on the use of ethnographic methods through a reluctance to be observed whilst undertaking organisational practices (see Hughes, 1999). A sample was chosen from those companies who had responded to the questionnaire survey, an advantage of which was that contextual information had already been gained to help inform the interview schedule.

A total of six in-depth semi-structured interviews were undertaken with music industry workers at the offices of companies over a two-week period in April 2006. Six is a small number of interviews; however the study employs a multimethod approach in which each method is applied with reference to the others to achieve the research aims (see McKendrick, 1999), and the interviews are therefore not the only basis of these research findings. Additionally, access to contacts within the companies proved difficult and it has become obvious during the course of the study that a good base of contacts can only be developed given sufficient time (more than was available in this particular study). Those companies with whom interviews were carried out were selected on the basis of having business links both within London and the UK and across other territories, allowing the analysis of these links. The companies were involved in record label and publishing activities, and ranged from small (one employee) to large independent companies (150 employees). Grounded theory was selected as the method of analysis for this study, the central features of which are the 
development of theory out of data and an iterative approach in which data collection and analysis proceed in tandem.

\section{London's Musical Knowledge Networks}

Face-to-face networking and the development of relationships of trust are considered crucial to the competitiveness of the creative industries (Crewe and Beaverstock, 1998). Interview participants suggested that in London's recorded music industry face-to-face contact was especially important in the early stages of a relationship when trust is yet to be achieved. For example a company, which I shall call Evident Music, has recently spent time developing a working relationship with a small specialist Internet company to develop technologies for the downloading of music to mobile phones. It was necessary for Evident Music to work with such a company from another specialist area to develop and provide such a service, as the necessary knowledge is not internal to the music industry. Furthermore, there is a large risk inherent to such new technologies, and Evident Music therefore considered it important to development a relationship with a company they could trust to provide the product. Developing trust reduces or removes the uncertainty surrounding competence and negotiation (Törnqvist, 2004). Furthermore, once such contacts are established, renewal can be achieved even after a significant gap in time:

“I'm meeting someone later this week who I haven't actually seen for about three months, and it doesn't matter because we haven't had anything particular to discuss sort of business wise, but now there is something on the horizon and we establish contact." (Male employee of a 
family-owned independent music publishing company located in the Notting Hill cluster)

However, while infrequent face-to-face may be sufficient for business relationships, more frequent face-to-face does facilitate the building of more personal relationships (see for example Power and Jansson, 2004, on Stockholm's music industry):

"...we have very strong relationships with magazines because we can go and see them face-to-face and just go for a drink with them or go for dinner, but you see a lot of people at gigs and stuff anyway..." (Female employee of a small independent record label located in the Notting Hill cluster)

One participant working in the metal music genre suggested that networking was particularly social:

“There's a horrendous amount of drinking going on in the metal industry, there's this huge drinking culture which probably helps to develop relationships." (Male employee of a media company and record label located in the Camden cluster)

The dynamics of these social relationships then, especially in non-mainstream musical genres, would appear to be built around an informality that blurs the business-social divide and transgresses the boundaries of the firm (see Pratt, 2000). As the same participant suggested: 
"It's hard to describe how it works but it does work, you build up a relationship with people and it's just easier to pick up the phone and ask them for something, and you don't feel necessarily cheeky when you're asking for something that is a bit cheeky because you know the person well enough... when you've seen someone drunk, you're like well l've seen you at you're lowest so I don't have to hold back." (Male employee of a media company and record label located in the Camden cluster)

Responses from the participants suggest that all music industry companies of a similar size within the UK share a social context and understanding of the business. This allows for the exchange of both tacit and codified knowledge, especially where established business and social relationships have been developed through frequent face-to-face contact. However, participant responses suggested that competition between companies inevitably limits knowledge transfer. Industry actors are in constant competition, particularly those working for companies in the same genre, as they race to sign up new musical prospects ahead of their competitors and mount competing promotional campaigns to achieve the largest sales volumes. Competition is exacerbated by spatial proximity, as ease of observation means that both success and failure is more apparent to local competitors. Therefore little information is shared directly between competing companies when it is felt that competitive advantage may be compromised. However, with so many collaborations occurring in the industry, particularly between companies involved in different activities, information of substantial value may be directly shared when it is expected to 
result in valuable information in return or benefit the performance of the collaboration:

"[In] competitive business little is shared. When you're talking about something that each company may have in common which can help each other, then that information is shared and people meet up and they talk about it." (Male director of a family-owned independent music publishing and film and TV music production company located in the Soho cluster)

This is of course not exclusive to the music industry, but is a characteristic of almost all industrial competition, with larger companies offering mutual support to smaller companies with which they are involved (see for example Pandit and Cook, 2005):

“...for a lot of the small companies that we do work with we're more than happy to help...I think we're actually quite nurturing as a company we'd rather help people than alienate them, but still at the same time there is always going to be competition." (Female employee of a small independent record label located in the Notting Hill cluster)

There are also more indirect forms of knowledge transfer that are characteristic of the music industry in particular and creative industries in general. For example, due to the proximity of music companies in London to their competition, creative knowledge is often gained by observation and transfer by freelance skilled labour. Likewise, it can also be gained through the types of 
cross-firm friendships discussed previously, which allow informal transfer even when companies are in competition.

Wolfe and Gertler (2004) suggest that for small and medium firms an essential piece of knowledge concerns conditions in external markets. It was suggested by participants that each music industry in each territory requires a different way 'working of the market'. As global distribution and cultural links are selective, musical releases have the potential to be a success in one territory and a failure in another (Connell and Gibson, 2003) if appropriate marketing strategies are not implemented. One example of success is a rock band signed to an independent record label; I shall call them the 'The Physic Celts'. The band come from the UK and enjoy strong domestic success. However, unlike many other UK bands, they and their record label have been able to translate domestic success to the US market. This has been in large part due to the way the band is marketed in the US. In order to gain access into that particular sales market, the UK based record label has an agreement to use the networks of one of the industry's global majors. As the quote below highlights, the label is aware that market success has come from allowing the major to use an appropriate marketing strategy based on their knowledge of the territory:

“...we're very realistic about what we can do and what we can't... we just go over and see what's going on and try and guide them in the way we would want to do things... but they'll have to do things their way... the UK model wouldn't necessarily work in the States..." (Female employee of a small independent record label located in the Notting Hill cluster) 
Likewise, the band has also enjoyed success in Europe more widely, as well as in Australia and Japan, but in these territories the marketing is different, operating through an independent marketing structure. Different strategies therefore appear to work in certain territories. However, knowing which strategy to employ requires a certain amount of learning; but how is this learning facilitated? From participant responses there would appear to be two main strategies adopted by music industry companies. Firstly, expansion into a new territory, which allows direct learning of each market by the staff based at a company office located within that territory. Each office in each territory is specialised to work to that specific market. In the case of some firms, main offices are based elsewhere in the world and the London office has been opened to deal specifically with the UK market. One participant suggested that company's main office in Germany would not be able to work the UK market directly from Germany because of the lack of 'local' knowledge:

"I know they couldn't do our job from Germany because they wouldn't have a clue how to work the UK market because they're so different." (Male employee of a media company and record label located in the Camden cluster)

Because of the differences in context, many strategies and technologies from abroad may not be able to be appropriated in the UK. However, there will be many things that can be appropriated and thus can improve the way business is undertaken in the UK. This was highlighted by the same participant: 
"Actually one thing I have done a couple of times that the MD and company founders asked me to go and do is go to America and see how they work over there. I've been to two trips, we've got an office in LA and I've spent a couple of weeks there and I definitely can see l've brought back stuff from there that I can apply here. There is a lot I can't because of the way the market works there differently... but there is a lot of stuff that I've learnt from them which is beneficial over here." (Male employee of a media company and record label located in the Camden cluster)

This suggests the use of a management strategy that attempts to foster knowledge transfer across large geographical distances. Such approaches then are not aimed at replicating approaches used elsewhere, but rather at allowing learning from the experience of others (Alvesson, 2004). As one participant stated:

"What it does do is gives rise to an element of more bilateral kind of working patterns whereby rather than it mainly being you trying to export stuff, you end up trying to find something that 'great it should be like that over here', and there's a lot more bilateral stuff going on no matter what territory you're dealing with..." (Male employee of a family-owned independent music publishing company located in the Notting Hill cluster)

This type of knowledge management internal to music industry firms means that tacit knowledge can be uncoupled from any supposed 'local fix' (see Faulconbridge, 2006a) within a given cluster of music industry companies. The second strategy is to develop relationships with what interview participants 
termed 'agents'. These are skilled people or companies based within the territory. Such links allow smaller companies access into territories without the financial risk of setting up a new office, and give the benefit of access to local knowledge of the business and social-cultural networks operating within the territory. The benefits of expansion or the use of agents are however not only limited to access into wider markets. They also allow for the development of 'communities' of learning that stretch knowledge transfer beyond scale-defined boundaries (Faulconbridge, 2006a):

“...we're feeding back off our agents and clients, in terms of music one might say, but also in terms of technology, in terms of marketing, we're all very involved and quite close in that regard, in terms of PR, in terms of how to do things, and we feed off and we give advice and help them, and if they come up with any ideas it's always useful to hear from them." (Male director of a family-owned independent music publishing and film and TV music production company located in the Soho cluster)

Once such communities are in place, which transcend the differences in social and business context, knowledge can be transferred freely between music industry companies, especially when well established.

Stretching knowledge networks: a relational perspective

It remains for the strands of the above discussion to be drawn together. This is initially attempted diagrammatically in Figure 4, a re-working of Bathelt et al's buzz and pipeline diagram (2004, pg.46), which gives a simplified 
representation of the relational conceptualisation developed in this study. The idea of a shared social context is retained, allowing two-way 'local' information and knowledge networking. The previous global pipelines conceptualisation of non-local knowledge transfer is replaced with two-way global information and knowledge networking, facilitated through certain organisational forms. The constitutive elements of the diagram warrant more detailed discussion. Responses from the interviews and questionnaire survey show that, despite arguments for a stretched-out sociality (see Hubbard, 2006), those working in London's music industry continue to consider face-to-face contact important. Responses supported Leyshon et al's (1998) assertion that production in the music industry is a 'transactional, information-rich and highly discursive process'. Formal knowledge transfer within the shared context is extremely dependent on competition. If firms are in co-operation, knowledge may be shared directly. However, because competition means that accessing trust in the formal sector is problematic, it is apparent that often relationships of trust are more easily developed in informal, social ways (see Banks et al, 2000) in London's bars, cafés, restaurants, and in particular at live music shows. It has been widely suggested that buzz results from serendipitous encounters between people working in the same professional domain (Leamer and Storper, 2001). They also play an important role in creating a sense of community (Nachum and Keeble, 2003), particularly in non-mainstream genres where often camaraderie is felt that facilitates the building of friendships, collaborations, and the flow of information (see for example Hoyler and Mager, 2005). These informal networks transgress the boundaries of the firm and allow the exchange of harder knowledge (Brown et al, 2000). However, responses highlight that it is important however not to overstate the local scale at the expense of developing 
an understanding of the role of global flows (see Amin and Thrift, 1992, Boggs and Rantisi, 2003, Gibson and Kong, 2005, Scott et al, 2001). It is clear from the interviews that many firms in the recorded music industry value opportunities for learning that stretch far beyond the spatial limits of a given cluster, supporting similar findings by Power and Hallencreutz (2002) for the music industry in Stockholm.

\section{Conclusions}

The findings of this paper suggest that high degrees of firm-level integration into the wider global music industry confer major advantages on London's recorded music industry. However, as Morgan (2004) argues, spatial reach should not be conflated with a social depth that allows for social reciprocity and exchange of tacit knowledge. In order for London music companies to be able to deal in foreign markets, they must develop organisational connections that will facilitate learning and the sharing of knowledge across cultural and economic boundaries. Once these links are established to other territories, they provide a mechanism for transferring tacit knowledge of large geographical distances. However, supporting the argument of Morgan it would appear that they do not offer the same scope for trust, reciprocity and friendship as is afforded by frequent face-to-face contact. Organisational connections then can at most only offer a partial substitute for geographical proximity, especially for those already embedded in communities of practice.

This study has limited scope, but nevertheless provides a useful point of departure for further work on clustering and knowledge networks, particularly in 
the cultural industries. For example, Morgan suggests that a key question for future research is how geographical and relational proximity are evolving into 'complex ecologies composed of different organisations that straddle multiple spatial scales" (2004, pg.13). There is in particular scope for analysis of the role that temporary organisations (see for example Asheim, 2002) and skilled labour play within the socially embedded linkages of project-based ecologies in the music industry (see Power and Hallencreutz, 2002).

\section{References}

Allen, J 2000 Power/economic knowledge; symbolic and spatial formations in Bryson, J R, Daniels, P W, Henry, N and Pollard, J eds Knowledge, Space, Economy, London, Routledge

Aksoy, A and Robins, K 1992 Hollywood for the $21^{\text {st }}$ century: global competition for critical mass in image markets Cambridge Journal of Economics 16 1-22

Alvesson, M 2004 Knowledge work and knowledge intensive firms Oxford University, Oxford

Amin, A 2000 Spatialities of globalization Environment and Planning A 34 385399

Amin, A and Cohendet, P 1999 Learning and adaptation in decentralised business networks Environment and Planning D 17 87-104 
Amin, A and Cohendet, P 2000 Organizational learning and governance through embedded practices Journal of Management and Governance 4 93-116

Amin, A and Thrift, N 1992 Neo-Marshallian nodes in global networks International Journal of Urban and Regional Research 16 571-587

Amin, A and Thrift, N 2000 Intervention: What kind of economic theory for what kind of economic geography? Antipode 32 (1) 4-9

Asheim, B T 2002 Temporary organisations and spatial embeddedness of learning and knowledge creation Geografiska Annaler B 84 (2) 111-124

Banks, M, Lovatt, A, O'Connor, J and Raffo, C 2000 Risk and trust in the cultural industries Geoforum 31 (4) 453-464

Bassett, K, Griffiths, R and Smith, I 2002 Cultural industries, cultural clusters and the city: the example of natural history film-making in Bristol Geoforum 33 165-177

Bathelt, H, Malmberg, A and Maskell, P 2004 Clusters and knowledge: local buzz, global pipelines and the process of knowledge creation Progress in Human Geography 28 (1) 31-56 
Beaverstock, J V, Smith, R G and Taylor, P J 1999 A roster of world cities Cities $16445-458$

Beaverstock, J V, Smith, R G and Taylor, P J 2000 World city network: a new metageography? Annals of the Association of American Geographers 90 (1) $123-134$

Beaverstock, J V, Smith, R G and Taylor, P J 2003 The global capacity of a world city: a relational study of London" in Kofman, E, and Youngs, G eds Globalization, Theory and Practice $\left(2^{\text {nd }}\right.$ Ed.), Continuum, London

Boggs, J S and Rantisi, N M 2003 The 'relational turn' in economic geography Journal of Economic Geography 3 109-116

Brown, A, O'Connor, J and Cohen, S 2000 Local music policies within a global music industry: cultural quarters in Manchester and Sheffield" Geoforum 31 437-451

Bunnell, T G and Coe, N M 2001 Spaces and scales of innovation Progress in Human Geography 24 (4) 569-589

Burnett, R 1996 The Global Jukebox: The International Music Industry, Routledge, London 
Christopherson, S and Storper, M 1986 The city as studio; the world as back lot: the impact of vertical disintegration on the location of the motion picture industry Environment and Planning D 4 305-320

Coe, N M 2000 The view from out west: embeddedness, inter-personal relations and the development of an indigenous film industry in Vancouver Geoforum 31 391-407

Coe, N M 2001 A hybrid agglomeration? The development of a satelliteMarshallian industrial district in Vancouver's film industry Urban Studies 38 (10) $1753-1775$

Collis, J 2001 The musicians' bible 2002 Penguin, London

Connell, J and Gibson, C 2003 Sound Tracks: Popular music, identity, and place Routledge, London

Cook, G and Pandit, N 2005 Cluster dynamics, cluster development and innovation: Insights from broadcasting in three UK city-regions GaWC Research Bulletin 184 (http://www.lboro.ac.uk/gawc) Accessed 1 September 2006

Crewe, L and Beaverstock, J 1998 Fashioning the city: cultures of consumption in contemporary urban spaces Geoforum 29 (3) 287-308 
DCMS 2001a Creative Industries Mapping Document 2001 Creative Industries Task Force, Department for Culture, Media and Sport, London

DCMS 2001b Banking on a hit: The funding dilemma for Britain's music business Department for Culture, Media, and Sport, London (http://www.culture.gov.uk) Accessed 12 July 2006

The Economist 2000 January $15^{\text {th }}$

Faulconbridge, J R 2006a Stretching tacit knowledge beyond a local fix? Global spaces of learning in advertising professional service firms Journal of Economic Geography 6 (4) 517-540

Faulconbridge, J R 2006b London and New York's advertising and law clusters and their networks of learning GaWC Research Bulletin 190 (http://www.lboro.ac.uk/gawc) Accessed 1 May 2007

The Financial Times 2000 January $11^{\text {th }}$

Gertler, M S 2001 Best practice: geography, learning and the institutional limits to strong convergence Journal of Economic Geography 1 5-26

Gertler, M S 2003 Tacit knowledge and the economic geography of context Journal of Economic Geography 3 75-99 
Gibson, C and Kong, L 2005 Cultural economy: a critical review Progress in Human Geography 29 (5) 541-561

Gordon, I R and McCann, P 2003 Industrial clusters: complexes, agglomeration and/or social networks? Urban Studies 37 (3) 513-532

Grabher, G 2001 Ecologies of creativity: The village, the group, and the heterarchic organisation of the British advertising industry Environment and Planning A 33 351-374

Grabher, G 2002 The project ecology of advertising: task, talents, and teams Regional Studies 36 (3) 245-262

The Guardian Business 2006 July $13^{\text {th }}$ (http://www.business.guardian.co.uk) Accessed July 132006

Hesmondhalgh, D 1996 Flexibility, post-fordism and the music industries Media, Culture and Society 18 469-488

Hoyler, M and Mager, C 2005 HipHop ist im Haus: cultural policy, community centres, and the making of Hip-Hop music in Germany Built Environment 31 (3) 237-254

Hubbard, P J 2006 City Routledge, London 
Hughes, A 1999 Constructing economic geographies from corporate interviews: insights from a cross-country comparison of retailer-supplier relationships Geoforum 30 363-374

IFPI 2005 IFPI released definitive statistics on global market for recorded music (http://www.ifpi.org) Accessed 1 February 2006

Kloosterman, R C 2005 Come together: an introduction to music and the city Built Environment 31 (3) 181-191

Kräkte, S 2003 Global media cities in a worldwide urban network European Planning Studies 11 (6) 605-628

Kräkte, S and Taylor, P J 2004 A world geography of global media cities European Planning Studies 12 (4) 459-477

Leamer, E and Storper, M 2001 The economic geography of the internet age Journal of International Business Studies 32 (4) 641-655

Leyshon, A, Matless, D and Revill, G 1998 The place of music The Guildford Press, New York

Leyshon, A, Webb, P, French, S, Thrift, N and Crewe, L 2005 On the reproduction of the musical economy after the Internet Media, Culture \& Society 27 (2) 177-209 
Martin, R and Sunley, P 2003 Deconstructing clusters: chaotic concept or policy panacea? Journal of Economic Geography 3 5-35

Maskell, P and Malmberg, A 1999 Localised learning and industrial competitiveness Cambridge Journal of Economics 23 167-185

McKendrick, J H 1999 Multi-method research: an introduction to its application in population geography Professional Geographer 51 (1) 40-50

Morgan, K 2004 The exaggerated death of geography: learning, proximity and territorial innovation systems Journal of Economic Geography 4 3-21

Morley, D and Robins, K 1995 Spaces of identity: global media, electronic landscapes and cultural boundaries Routledge, London

Nachum, L and Keeble, D 2003 Neo-marshallian clusters and global networks: the linkages of media firms in central London Long Range Planning 36 $459-480$

Negus, K 1992 Producing Pop - Culture and Conflict in the Popular Music Industry, Arnold, London

Negus, K 1999 Musical Genres and Corporate Cultures, Routledge, London 
Newman, P and Smith, I 2000 Cultural production, place and politics on the south bank of the Thames International Journal of Urban and Regional Research 24 (1) 9-24

Pandit, N and Cook, G 2005 Clusters, economic geography and regional development policy: Insights from the UK broadcasting industry GaWC Research Bulletin 185 (http://www.lboro.ac.uk/gawc) Accessed 1 September 2006

Pinch, S, Henry, N, Jenkins, M and Tallman, S 2003 From 'industrial districts' to 'knowledge clusters': a model of knowledge dissemination and competitive advantage in industrial agglomerations Journal of Economic Geography 3 373-388

Power, D and Hallencreutz, D 2002 Profiting from creativity? The music industry in Stockholm, Sweden and Kingston, Jamaica Environment and Planning A 34 1833-1854

Power, D and Jansson, J 2004 The emergence of a post-industrial music economy? Music and ICT synergies in Stockholm, Sweden Geoforum 35 425-439

Pratt, A C 2000 New media, the new economy and new spaces Geoforum 31 $425-436$ 
Robins, K 1995 The new spaces of global media in Johnston, R J, Taylor, P J and Watts, M J eds Geographies of Global Change, Blackwell, Oxford

Sassen, S 1991 The Global City Princeton University Press, Princeton

Sassen, S 1994 Cities in a World Economy Pine Forge Press, London

Scott, A J 1996 The craft, fashion and cultural-products industries of Los Angeles: competitive dynamics and policy dilemmas in a multisectoral image-producing complex Annals of the Association of American Geographers 86 (2) 306-323

Scott, A J 1997 The cultural economy of cities International Journal of Urban and Regional Research 21 (2) 323-339

Scott, A J 1999 The US recorded music industry: on the relations between organisation, location, and creativity in the cultural economy Environment and Planning A 31 1965-1984

Scott, A J 2000a The cultural economy of Paris International Journal of Urban and Regional Research 24 (3) 567-582

Scott, A J 2000b The Cultural Economy of Cities: Essays on the Geography of Image-Producing Industries Sage, London 
Scott, A J 2001 Capitalism, cities, and the production of symbolic forms Transactions of the Institute of British Geographers 26 (1) 11-23

Scott, A J 2002 A new map of Hollywood: the production and distribution of American motion pictures Regional Studies 36 957-975

Scott, A J, Agnew, J, Soja, E W and Storper, M 2001 Global city-regions in Scott, A J ed Global City-Regions: Trends, Theory, Policy Oxford University Press, Oxford

Storper, M and Christopherson, S 1987 Flexible specialisation and regional agglomerations: the case of the U.S. motion picture industry Annals of the Association of American Geographers 77 (1) 104-117

Storper, M and Venables, A J 2004 Buzz: face-to-face contact and the urban economy Journal of Economic Geography 4 351-370

The Times 2006 May $24^{\text {th }}$

The Times Online (2006) July $13^{\text {th }}$ (http://www/timesonline.co.uk) Accessed 13 July 2006

Törnqvist, G 2004 Creativity in time and space Geografiska Annaler 86b (4) $227-243$ 
Wolfe, D A and Gertler, M 2004 Clusters from the inside and out: local dynamics and global linkages" Urban Studies 41 (5/6) 1071-109 


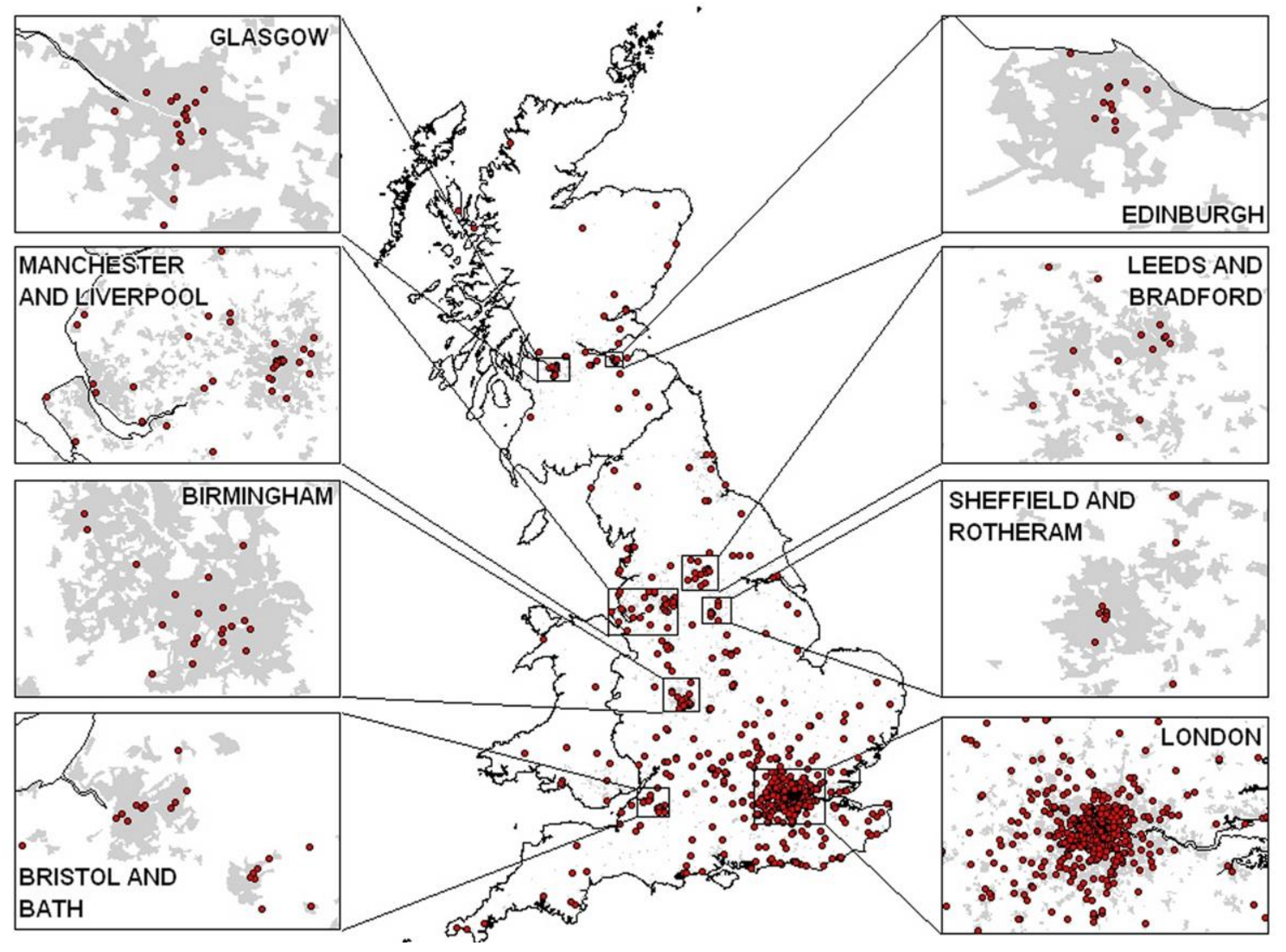

Figure 1



Figure 2 




Figure 3

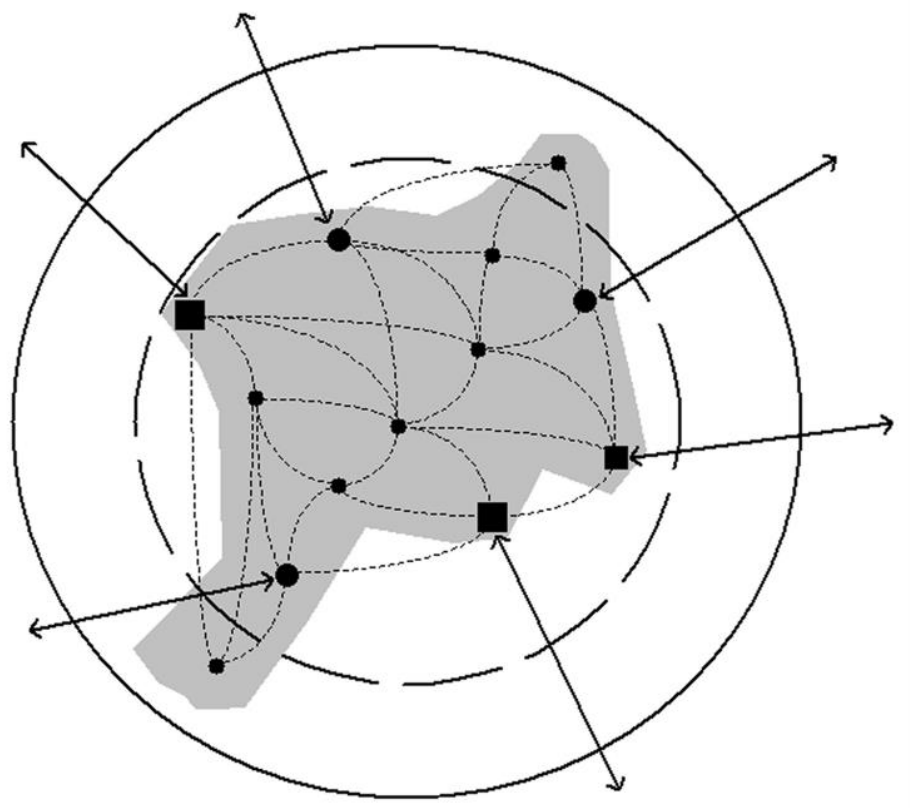

Multinational Corporations and Subsidiaries

Larger Independents

Small Independents

London

United Kingdom

Shared social context

values, attitudes

and interpretative schemes

Two-way local information and knowledge networking within

the shared social context; formal

and informal face-to-face transfer determined by competition

Two-way global information and knowledge networking outside the shared social context; use of territory offices/agents with local knowledge of territories

Figure 4 